\title{
The amino-acid composition of three mixed diets
}

\author{
BY B. P. HUGHES* \\ Medical Research Council Department of Experimental Medicine, \\ University of Cambridge
}

(Received 27 December 1958-Revised 24 March 1959)

\begin{abstract}
Although diets commonly consumed in this country include a large number of different items, the chief sources of protein are relatively few in number. Thus, on the average, in the United Kingdom somewhat over $50 \%$ of the total protein is derived from carcass meat, dairy products and eggs, about $40 \%$ from cereals, mainly wheat products, and only $10 \%$ from miscellaneous vegetables and fruits. Of this final $10 \%$, the contribution of fruits is only about $2 \%$ and the largest amount of vegetable protein is derived from potato (Ministry of Agriculture, Fisheries and Food: National Food Survey Committee, 1957). To calculate the amino-acid intake provided by this kind of diet it is clearly essential to have reliable information about the composition of foods of animal origin and also of cereals. Uncertainties about the composition of vegetables and fruits will be less important.

Much information on the amino-acid content of proteins and foods has been already collected in various publications (Block \& Bolling, I95 I H Harvey, r956; Orr \& Watt, I957), but there are still considerable gaps in our knowledge, and it seemed worth while to inquire whether the data now available were sufficient for calculating with reasonable accuracy the daily intakes of the different amino acids provided by a particular diet and to see what simplifications, if any, could be introduced. In order to do so, tables of the amino-acid composition of the important protein foods have been compiled. Three different mixtures corresponding to three diets have been prepared and directly analysed by the Moore and Stein technique (Hughes, I958), the amounts of the different amino acids found then being compared with figures calculated from the published data.
\end{abstract}

\section{METHODS}

\section{Diets}

The first diet was that of the author, living his normal life and eating his accustomed assortment of foods, which contained both animal and vegetable protein. The second was that of a child of 18 months, the daughter of a colleague, and the third was a typical 'vegan' diet which contained no animal protein. The first two diets corresponded to the actual food eaten by the two individuals over a period of a week, and the composition of the last was arrived at by scrutinizing dietary records supplied by a number of vegans and drawing up an 'average diet' designed to provide sufficient

* Present address: Institute of Neurology, The National Hospital, Queen Square, London, W.C. I. 
calories for an adult and an amount of plant protein similar to that consumed by vegans and derived from the same kind of foodstuffs.

The composition of the three diets is summarized in Table $I$.

It matters little that the first two diets, representing as they do the food intake of two individuals over a limited period, may not be typical, since the object of the study was to see if the composition of a particular diet could be computed.

Table 1. Composition of mixed diets

\begin{tabular}{lccc}
\multicolumn{1}{c}{ Item } & (g/day) & & \\
Meat & 'Normal' adult & Child & Vegan adult \\
Fish & 103 & 4 & 0 \\
Eggs & 30 & 3 & $\circ$ \\
Milk and cheese & 20 & 0 & $\circ$ \\
$\quad$ (including ice-cream) & 254 & 439 & 0 \\
Green vegetables & & & \\
Potatoes & 9 & 0 & 223 \\
Legumes & 76 & 20 & $8 \mathrm{I}$ \\
Other vegetables & $2 \mathrm{I}$ & 8 & 56 \\
Nuts & 77 & 0 & 181 \\
Fruit & 0 & 0 & 64 \\
Bread: white & $4 \mathrm{I}$ & $3 \mathrm{I}$ & 322 \\
$\quad$ brown & 157 & 9 & 0 \\
Wheat products & $2 \mathrm{I}$ & 44 & $220^{*}$ \\
(including cakes and & 32 & 42 & $70^{*}$ \\
pastry) & & & \\
Other cereals & 0 & 0 & 26 \\
Soup & 0 & 50 & 0 \\
Jelly & 0 & 23 & 0 \\
Protein (N $\times 6 \cdot 25)$ & $62 \cdot 5(63 \cdot 1)$ & $27 \cdot 5(28 \cdot 1)$ & $71 \cdot 2(67 \cdot 5)$
\end{tabular}

Figures in parentheses are values estimated from food tables.

* All wholemeal.

\section{Calculation of the amino-acid content of the diets}

A survey of the relevant literature, similar to that carried out previously (Hughes, I955), but including some new information, showed that there are almost complete data for the common foods of animal origin and also for the whole grains of cereals. Lack of information on milling fractions, flours and other cereal products had partly been made good by recently published figures for wheat flours of different rates of extraction and for bread (Nunnikhoven, I955; Hepburn, Lewis \& Elvehjem, r957; McDermott \& Pace, I957).

The amino-acid composition of foodstuffs contributing appreciable amounts of protein to the diets analysed is given in Tables 2 and 3 . Wherever possible the figures are the average of the most representative values published in the literature. Only a single set of figures is given for meat, although there is an extensive literature giving data for most kinds of meat, both raw and processed. Variations of between ro and $20 \%$ in the content of individual amino acids, on a total nitrogen basis, are common, but there do not seem to be any systematic differences between meat from different species. The less complete information for poultry and meat offal suggests that little additional error is introduced if the figures are applied to these foods also, but when 
genuine differences appear to exist separate values are quoted. There are as yet insufficient published data for deciding whether or not an analogous situation exists with fish, but it is possible that fish may vary in composition more than meat does (Orr \& Watt, I957).

The amino-acid content in g/day was calculated from data in Tables 2 and 3 together with the values for the total nitrogen in the different foods from the tables of McCance \& Widdowson (1946). The total nitrogen in cashew nut, however, was taken from the tables of Watt, Merrill, Orr, Wu \& Pecot (r950).

Table 2. Amino-acid content of foods of animal origin

\begin{tabular}{|c|c|c|c|c|c|}
\hline \multicolumn{6}{|c|}{$(\mathrm{g} / \mathrm{I} 6 \mathrm{~g}$ total $\mathrm{N})$} \\
\hline Amino acid & $\begin{array}{l}\text { Meat and } \\
\text { meat products }\end{array}$ & Gelatin* & White fish & $\begin{array}{l}\text { Milk and } \\
\text { cheese }\end{array}$ & Whole egg \\
\hline Arginine & $6 \cdot 6,6 \cdot 0 \dagger$ & $7 \cdot 7$ & $5 \cdot 7$ & $3 \cdot 6$ & 6.4 \\
\hline Cystine & I.3 & Trace & $I \cdot I$ & $0.8,0.5 t$ & $2 \cdot 0$ \\
\hline Histidine & $3 \cdot 2$ & 0.7 & $2 \cdot 1$ & $2 \cdot 2$ & $2 \cdot 5$ \\
\hline Isoleucine & $5 \cdot 1$ & $\mathrm{I} \cdot 5$ & $5 \cdot 1$ & $6 \cdot 2$ & $5 \cdot 8$ \\
\hline Leucine & $7 \cdot 9,9 \cdot 0 \S$ & $2 \cdot 9$ & $7 \cdot 6$ & $9 \cdot 9$ & $8 \cdot 9$ \\
\hline Lysine & $8 \cdot 2$ & $4 \cdot 0$ & $9^{\circ} 0$ & $7 \cdot 8$ & $6 \cdot 7$ \\
\hline Methionine & $2 \cdot 4$ & 0.8 & $2 \cdot 9$ & $2 \cdot 4$ & $3 \cdot I$ \\
\hline Phenylalanine & $4 \cdot 1,5 \cdot 29$ & $2 \cdot 0$ & $3 \cdot 7$ & $5 \cdot 1$ & $5 \cdot 3$ \\
\hline Threonine & $4 \cdot 5$ & $I \cdot 9$ & $4 \cdot 5$ & $4 \cdot 6$ & $5 \cdot 2$ \\
\hline Tryptophan & $\mathrm{I} \cdot 3$ & 0 & $\mathrm{I} \cdot \mathrm{O}$ & $\mathrm{I} \cdot 4$ & $I \cdot 7$ \\
\hline Tyrosine & $3 \cdot 4$ & 0.2 & $3 \cdot 0$ & $5^{\cdot 6}$ & $4 \cdot 3$ \\
\hline Valine & $5 \cdot 3,6 \cdot 19$ & $2 \cdot 3$ & $5 \cdot 3$ & $7 \cdot I$ & $7 \cdot 2$ \\
\hline Alanine & $6 \cdot 2$ & $9 \cdot 7$ & $6 \cdot 0$ & $3 \cdot 6$ & - \\
\hline Aspartic acid & $9 \cdot 2$ & $5 \cdot 9$ & $9 \cdot 4$ & $8 \cdot 1$ & $10 \cdot 8$ \\
\hline Glutamic acid & $15 \% 4$ & $10 \cdot 0$ & $14{ }^{\circ} \mathrm{O}$ & $22 \cdot 3$ & $12 \cdot 4$ \\
\hline Glycine & 4.4 & $24 \cdot 2$ & $6 \cdot 1$ & $1 \cdot 9$ & $3 \cdot 8$ \\
\hline Proline & $4 \cdot 2$ & 14.4 & $5 \cdot 9$ & $9 \cdot 8$ & $4 \cdot 3$ \\
\hline Serine & $4^{\cdot I}$ & $3 \cdot 7$ & $5 \cdot 2$ & $5 \cdot 7$ & $7 \cdot 7$ \\
\hline
\end{tabular}

These values were obtained by averaging, wherever possible, those published in the literature, see p. 331 .

* Recalculated from Eastoe (I955)

$\dagger$ Liver, kidney, brain, rabbit carcass.

I Cheese.

$\S$ Liver, kidney, brain, heart, tongue.

g Liver, kidney, brain.

\section{Analysis of the mixed diets for amino acids}

Weighed amounts of the constituent foods were homogenized together in a Waring Blendor with the addition of water, and stored at $-20^{\circ}$ until analysed.

The total nitrogen and amino-acid contents of the homogenates were estimated by the methods described previously (Hughes, 1958).

\section{RESULTS}

Table 4 compares the values found by calculation with those got by direct analysis for the amounts of the common amino acids provided daily by the three diets. Lack of sufficient published data made it impossible to calculate the amounts of all the amino acids in the vegan diet. In addition, tryptophan was not determined on the homogenates, because the method of Graham, Smith, Hier \& Klein (1947) used previously (Hughes, 1958) for the estimation of this amino acid in potato was unsatisfactory when applied to these complex mixtures, an interfering purple colour being produced. McDermott 
Vol. 13

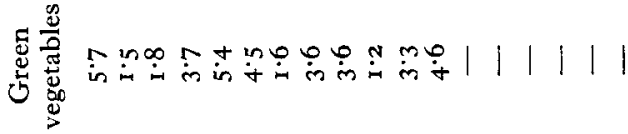

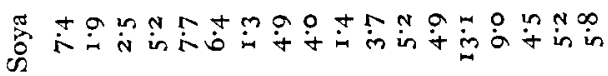

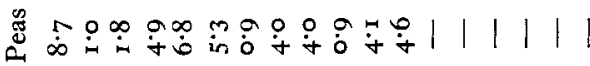

$\stackrel{\leftrightarrow}{2}$

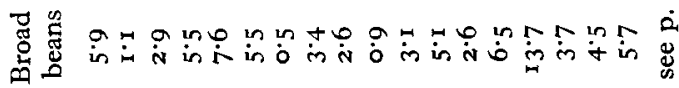

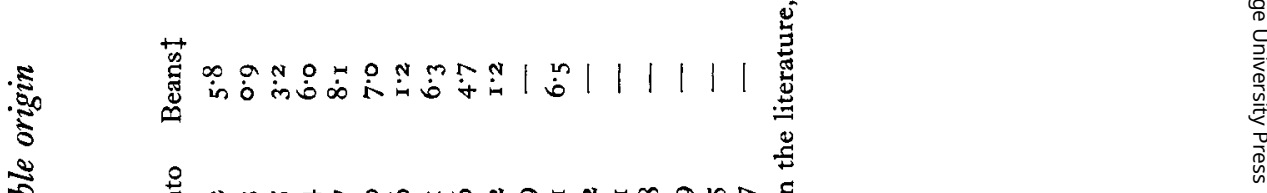

要

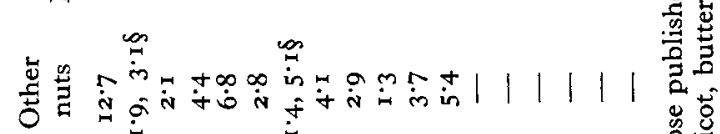

节

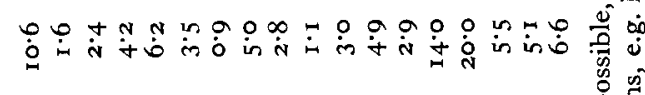

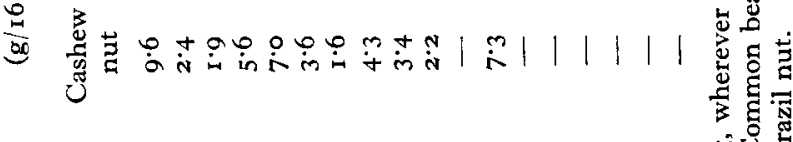

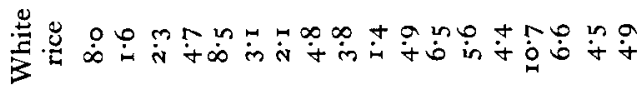

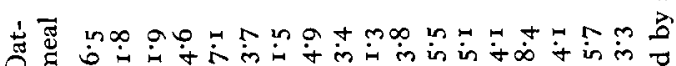

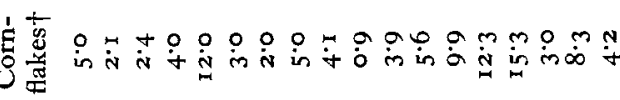

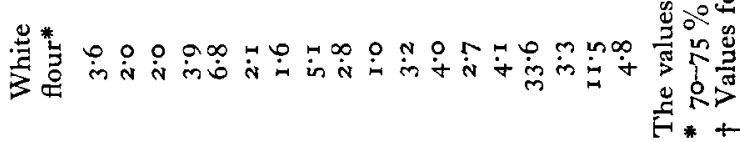

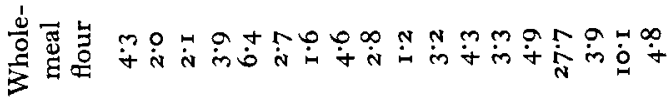

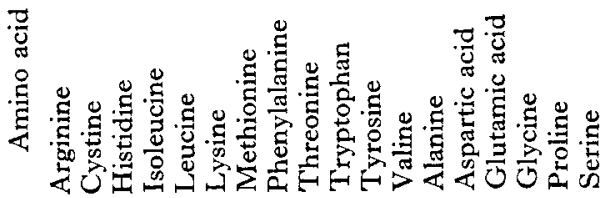


\& Pace (1957) report a similar difficulty in attempting to apply this method to the analysis of bread. Only the calculated values for tryptophan are therefore given.

For the two diets in which much of the protein is derived from cereals and from foods of animal origin, there is good agreement between the two sets of values, but agreement is much less satisfactory for the vegan diet, the calculated values generally being lower than those found by direct analysis. The discrepancy is particularly marked for phenylalanine and lysine.

Table 4. Comparison of the calculated (see p. 331) and found amino-acid composition of the mixed diets

\begin{tabular}{|c|c|c|c|c|c|c|c|}
\hline \multirow[b]{2}{*}{ Amino acid } & \multirow{2}{*}{$\begin{array}{c}\text { 'Definitely } \\
\text { safe } \\
\text { intake'* } \\
\text { (adult } \\
\text { male) }\end{array}$} & \multicolumn{2}{|c|}{ 'Normal' adult } & \multicolumn{2}{|c|}{ Child } & \multicolumn{2}{|c|}{ Vegan adult } \\
\hline & & Calculated & Found & Calculated & Found & Calculated & Found \\
\hline Arginine & - & 3.0 & $2 \cdot 6$ & $I \cdot I$ & $I \cdot O$ & 3.7 & $4 \cdot 4$ \\
\hline Cystine & - & 0.9 & $I \cdot 0$ & 0.3 & 0.3 & $I \cdot 0$ & $\mathrm{I} \cdot 3$ \\
\hline Histidine & - & $1 \cdot 4$ & $x \cdot 7$ & 0.6 & 0.6 & $I \cdot 3$ & $I \cdot 4$ \\
\hline Isoleucine & $1 \cdot 4$ & $3 \cdot I$ & $2 \cdot 6$ & 1.4 & $I \cdot 2$ & $2 \cdot 5$ & $2 \cdot 6$ \\
\hline Leucine & $2 \cdot 2$ & $4 \cdot 9$ & $4 \cdot 6$ & $2 \cdot 3$ & $2 \cdot 1$ & $3 \cdot 9$ & $4 \cdot 7$ \\
\hline Lysine & $I \cdot 6$ & $3 \cdot 6$ & $3 \cdot 6$ & $I \cdot 6$ & $I \cdot 6$ & $2 \cdot I$ & $2 \cdot 9$ \\
\hline Methionine & $2 \cdot 2 \dagger$ & $\mathrm{I} \cdot 3$ & $\mathrm{I} \cdot \mathrm{I}$ & 0.6 & 0.5 & 0.9 & 0.9 \\
\hline Phenylalanine & $2 \cdot 2 t$ & $2 \cdot 9$ & $2 \cdot 9$ & $\mathrm{I} \cdot 3$ & $I \cdot 3$ & $2 \cdot 7$ & 4.0 \\
\hline Threonine & $1 \cdot 0$ & 2.4 & $2 \cdot 2$ & $I \cdot I$ & $1 \cdot 1$ & $1 \cdot 9$ & $2 \cdot 2$ \\
\hline Tryptophan & 0.5 & 0.7 & - & 0.3 & - & 0.6 & 一 \\
\hline Tyrosine & - & $2 \cdot 4$ & $2 \cdot 3$ & $1 \cdot 2$ & $I \cdot 2$ & $I \cdot 9$ & $2 \cdot 3$ \\
\hline Valine & $1 \cdot 6$ & $3 \cdot 2$ & $3 \cdot 3$ & $x \cdot 6$ & $I \cdot 5$ & $2 \cdot 9$ & $3 \cdot 2$ \\
\hline Alanine & - & $2 \cdot 5$ & $2 \cdot 7$ & 0.9 & $I \cdot O$ & - & $2 \cdot 7$ \\
\hline Aspartic acid & - & $4 \cdot 6$ & $4 \cdot 3$ & $\pi \cdot 8$ & $\mathrm{I} \cdot 9$ & - & $5 \cdot 3$ \\
\hline Glutamic acid & - & I4. I & $13 \cdot 0$ & $6 \cdot 1$ & $5 \cdot 8$ & - & $16 \cdot I$ \\
\hline Glycine & - & $2 \cdot 2$ & $2 \cdot 4$ & 0.8 & 0.9 & 一 & $2 \cdot 8$ \\
\hline Proline & - & $5^{\circ} \mathrm{O}$ & $5 \cdot 2$ & $2 \cdot 5$ & $2 \cdot 3$ & - & $5^{\circ} 0$ \\
\hline Serine & - & $3 \cdot \mathrm{I}$ & $2 \cdot 9$ & $I \cdot 4$ & $I \cdot 3$ & - & $3 \cdot 2$ \\
\hline $\begin{array}{l}\text { Cystine and } \\
\text { methionine }\end{array}$ & - & $2 \cdot 2$ & $2 \cdot I$ & 0.9 & 0.8 & $x \cdot 9$ & $2 \cdot 2$ \\
\hline
\end{tabular}

\section{DISCUSSION}

With the two diets containing animal protein, those of the 'normal' adult and of the child, there are some discrepancies between the calculated and found values that merit attention. For reasons indicated previously (Hughes, 1958), the analytical figures for methionine may be low, because large amounts of carbohydrates from the cereals and other vegetable foods are present in the mixtures. Consequently, because the errors in analysis of the different foods separately may be less than in the analysis of the mixture, the calculated figures for diets in which much of the protein comes from foods containing little carbohydrate are possibly more accurate. On the other hand, the calculated figures for cystine may be low because the method (Schram, Moore \& Bigwood, r954) used to estimate this amino acid is designed to eliminate losses known to occur when cystine-containing material is subjected to acid hydrolysis (Block \& 
Bolling, I95 I). Nevertheless, the values found by this method may also be low since Norris (1958), who analysed the same homogenates by means of enzyme hydrolysis combined with a microbiological technique, found about $40 \%$ more cystine than is reported here.

The calculated amounts of arginine and isoleucine in these two diets are higher than those found by analysis. The reason is not known, but some of the published data for isoleucine in foods may be too high on account of an unsuspected contamination of the isoleucine standards used with alloisoleucine (Smith \& Greene, 1948). For most of the other amino acids agreement between the calculated values and those found by analysis is within $10 \%$, a satisfactory result in view of the possible errors both in the calculation and in the analysis. From the published data, the amino-acid content of a diet in which most of the protein comes from cereals and foods of animal origin can thus be computed with fair success, and in particular the simplified presentation of the values for meat seems to be justified.

The less satisfactory agreement between the results of calculation and of analysis for the vegan diet is not wholly unexpected. A considerable amount of the total protein in this diet comes from nuts and leaf vegetables, which may vary in composition and for which only a few analyses have been published. Moreover lack of data made it necessary to omit from the calculation the smaller contributions of certain vegetables and fruits.

\section{Table 5. Amino-acid composition of diets determined by analysis}

\section{(g/16 g total $\mathrm{N})$}

$\begin{array}{lccc}\text { Amino acid } & \text { 'Normal' adult } & \text { Child } & \text { Vegan adult } \\ \text { Arginine } & 4 \cdot \mathbf{I} & 3 \cdot 7 & 6 \cdot 2 \\ \text { Cystine } & 1 \cdot 6 & 1 \cdot 2 & \mathbf{1} \cdot 8 \\ \text { Histidine } & 2 \cdot 7 & 2 \cdot 3 & 1 \cdot 9 \\ \text { Isoleucine } & 4 \cdot 1 & 4 \cdot 3 & 3 \cdot 6 \\ \text { Leucine } & 7 \cdot 4 & 7 \cdot 7 & 6 \cdot 6 \\ \text { Lysine } & 5 \cdot 8 & 5 \cdot 6 & 4 \cdot 1 \\ \text { Methionine } & 1 \cdot 8 & 1 \cdot 9 & 1 \cdot 2 \\ \text { Phenylalanine } & 4 \cdot 7 & 4 \cdot 8 & 5 \cdot 7 \\ \text { Threonine } & 3 \cdot 5 & 3 \cdot 9 & 3 \cdot 0 \\ \text { Tryptophan } & 1 \cdot 2 * & 1 \cdot 2^{*} & 0 \cdot 9 \\ \text { Tyrosine } & 3 \cdot 7 & 4 \cdot 2 & 3 \cdot 2 \\ \text { Valine } & 5 \cdot 3 & 5 \cdot 6 & 4 \cdot 5 \\ \text { Alanine } & 4 \cdot 3 & 3 \cdot 3 & 3 \cdot 8 \\ \text { Aspartic acid } & 6 \cdot 8 & 6 \cdot 9 & 7 \cdot 5 \\ \text { Glutamic acid } & 21 \cdot 0 & 20 \cdot 5 & 22 \cdot 6 \\ \text { Glycine } & 3 \cdot 8 & 2 \cdot 9 & 4 \cdot 0 \\ \text { Proline } & 8 \cdot 3 & 8 \cdot 6 & 7 \cdot 1 \\ \text { Serine } & 4 \cdot 7 & 4 \cdot 6 & 4 \cdot 5 \\ & * \text { Calculated value. } & & \end{array}$

In Table 5, the composition of the three diets is given as $\mathrm{g}$ amino acid/ $6 \mathrm{~g}$ total nitrogen (approximately $100 \mathrm{~g}$ protein); the figures are derived from direct analysis except for tryptophan. Expressed in this way the 'normal' adult's and child's diets are similar. Such differences as do exist, e.g. the smaller cystine content of the child's diet, can be attributed to differences between milk proteins and those of meat. By contrast the vegan diet provides, in general, less of the nutritionally most important 
amino acids. The larger amount of arginine in the vegan diet is due to the comparatively large quantities of nut protein it contains. However, at a daily protein intake of $60-70 \mathrm{~g}$, a diet of this composition does not show obvious amino-acid deficiencies, and, indeed, with the exception of the sulphur amino acids, both the vegan and 'normal' adult diets appear to supply the essential amino acids in excess of the amounts that Rose (1957) regards as 'definitely safe' ('Table 4). Nevertheless, since the conditions for optimum protein nutrition depend not only on the absolute amounts of the various amino acids in the diet, but also on their relative proportions (Elvehjem, 1956; Harper, 1958) and, further, since knowledge of the availability of amino acids in foods is far from complete, it would be unwise to stress this point too strongly.

In both the 'normal' adult and vegan diets the combined total of cystine and methionine is only just on the 'definitely safe' level for methionine in the absence of cystine, so that, even allowing for the sparing effect of cystine on methionine requirements (Rose, 1957), the diets seem to be rather deficient in the sulphur amino acids. However, because errors in determining the sulphur amino acids in carbohydrate-containing foods can sometimes lead to low results, this deficiency may be only apparent.

\section{SUMMARY}

I. Three mixtures corresponding to a 'normal' adult's diet, a child's diet and the diet of an adult consuming no animal protein, i.e. a vegan diet, have been prepared in the laboratory, their amino-acid composition being then determined by direct analysis.

2. Tables of the amino-acid composition of various foodstuffs have been compiled from published data and have been used to calculate the composition of the mixtures analysed.

3. The amounts of the various amino acids found by analysis and by calculation have been compared. Agreement between calculation and analysis was good for the first two diets, but less satisfactory for the vegan diet. It is concluded that the published information on amino acids in foods can be used successfully to estimate the composition of a diet in which most of the protein comes from foods of animal origin and from cereals.

4. The diets were compared on the basis of $\mathrm{g}$ amino acid/1 $6 \mathrm{~g}$ total nitrogen, and it was evident that in general the vegan diet contained less of the nutritionally most important amino acids.

I am indebted to DrF. Wokes for invaluable assistance in drawing up an 'average' vegan diet and to $\mathrm{Dr} \mathrm{E}$. M. Widdowson for advice and criticism. I would also like to thank my colleagues $\mathrm{Mr} \mathrm{D}$. A. T. Southgate for help in preparing the diets, and Mr J. Dickerson for supplying information on the child's diet. 
REFERENCES

Block, R. J. \& Bolling, D. (I95I). The Amino Acid Composition of Proteins and Foods, 2nd ed. Springfield, Ill.: C. C. Thomas.

Eastoe, J. E. (1955). Biochem. F. 6r, 589 .

Elvehjem, C. A. (1956). F. Amer, diet. Ass. 32, 921 .

Graham, C. E., Smith, E. P., Hier, S. W. \& Klein, D. (1947). F. biol. Chem. r68, 711.

Harper, A. E. (1958). Ann. N.Y. Acad. Sci. 69, 1025.

Harvey, D. (1956). Tech. Commun. Bur. Anim. Nutr., Aberd., no. I9.

Hepburn, F. N., Lewis, E. W. Jr. \& Elvehjem, C. A. (1957). Cereal Chem. 34, 312.

Hughes, B. P. (1955). Brit. F. Nutr. 9, 373.

Hughes, B. P. (1958). Brit. F. Nutr. 12, 188.

McCance, R. A. \& Widdowson, E. M. (1946). Spec. Rep. Ser. med. Res. Coun., Lond., no. 235.

McDermott, E. E. \& Pace, J. (1957). Brit. Y. Nutr. II, 446.

Ministry of Agriculture, Fisheries and Food: National Food Survey Committee (1957). Domestic Food Consumption and Expenditure, 1955. London: H.M. Stationery Office.

Norris, F. W. (1958). Private communication.

Nunnikhoven, R. (1955). De aminozuur-sammenstelling van tarweeiwitten in verband met de uitmalingsgraad alsmede de instrumentatie voor kolom-chromatografie. Thesis, University of Amsterdam.

Orr, M. L. \& Watt, B. K. (1957). Home Econ. Res. Rep. U.S. Dep. Agric. no. 4.

Rose, W. C. (1957). Nutr. Abstr. Rev. 27, 631 .

Schram, E., Moore, S. \& Bigwood, E. J. (1954). Biochem. F. 57, 33.

Smith, E. L. \& Greene, R. D. (1948). F. biol. Chem. 172, I I 1 .

Watt, B. K., Merrill, A. L., Orr, M. L., Wu, W. T. \& Pecot, R. K. (r950). Agric. Handb. U.S. Dep. Agric. no. 8, p. 147.

\title{
Distribution of chromium sesquioxide and polyethyleneglycol in the reticulo-rumen of cattle
}

\author{
By J. L. CORBET'T, J. F. D. GREENHALGH AND E. FLORENCE \\ Rowett Research Institute, Bucksburn, Aberdeen
}

(Received 1о Yanuary 1959)

The results of an experiment reported in an earlier paper (Corbett, Greenhalgh, Gwynn \& Walker, I958) showed that there were large differences in the patterns of excretion in faeces of the water-soluble food marker polyethyleneglycol and the insoluble marker chromium sesquioxide $\left(\mathrm{Cr}_{2} \mathrm{O}_{3}\right)$ when these substances were administered simultaneously twice daily to dairy cows. It was suggested that these differences arose primarily from a differential distribution of the two markers in the contents of the reticulo-rumen; and that polyethyleneglycol was probably associated mainly with the liquid phase of digesta and so was cleared from these organs more rapidly than the $\mathrm{Cr}_{2} \mathrm{O}_{3}$ which, it was suggested, was associated primarily with the dry matter. This paper describes experiments to test this hypothesis.

\section{EXPERIMENTAL}

Two $2 \frac{1}{2}$-year-old barren dry Friesian heifers weighing about 750 and $1000 \mathrm{lb}$ (animals $176 \mathrm{~A}$ and $177 \mathrm{~B}$ respectively) were housed in loose-boxes with sawdust for bedding. They were given $400 \mathrm{~g}$ of grass-meal cubes containing about $7 \cdot \mathrm{r} \% \mathrm{Cr}_{2} \mathrm{O}_{3}$ 